J. Dairy Sci. 96:4983-4992

http://dx.doi.org/10.3168/jds.2012-6197

(C) American Dairy Science Association ${ }^{\circledR}, 2013$.

\title{
Efficacy of extended cefquinome treatment of clinical Staphylococcus aureus mastitis
}

\author{
J. M. Swinkels, ${ }^{1}{ }^{1}$ P. Cox, $†$ Y. H. Schukken, $\ddagger$ and T. J. G. M. Lam§ \\ *MSD Animal Health, Global Ruminants Business Unit, Boxmeer, 5830 AA, the Netherlands \\ †MSD Animal Health, Research and Development, 49071, Beaucouzé, France \\ †Quality Milk Production Services, Department of Population Medicine and Diagnostic Sciences, College of Veterinary Medicine, \\ Cornell University, Ithaca, NY 14853 \\ §GD Animal Health Service, 7400 AA, Deventer, the Netherlands, and Faculty of Veterinary Medicine, Department of Farm Animal Health, \\ Utrecht University, 3508 TD, Utrecht, the Netherlands
}

\begin{abstract}
Clinical Staphylococcus aureus mastitis is difficult to cure. Extended antimicrobial treatment is often advocated as a practical approach to improve cure rates; however, scientific evidence of this hypothesis is lacking. A multi-centered, nonblinded, randomized, positive-controlled clinical trial was conducted in $5 \mathrm{Eu}-$ ropean countries - France, Hungary, Italy, the Netherlands, and the United Kingdom - to study the efficacy of an extended intramammary cefquinome treatment (5 d) compared with a standard intramammary cefquinome treatment $(1.5 \mathrm{~d})$ of Staph. aureus clinical mastitis. Least squares means estimates of bacteriological cure during lactation were 34\% [standard error (SE) $=9.9 \%$ for the standard treatment group and $27 \%$ $(\mathrm{SE}=8.4 \%)$ for the extended treatment group. In the final model, extended therapy was not significantly better. The only factor predicting bacteriological cure was pretreatment cow somatic cell count (SCC). Cows with $>250,000$ cells $/ \mathrm{mL}$ in milk before treatment were less likely to cure. Least squares means of clinical cure during lactation was $60 \%(\mathrm{SE}=19 \%)$ for the standard treatment group and $82 \%(\mathrm{SE}=12 \%)$ for the extended treatment group. In the final model, clinical cure after extended treatment was significantly better. Pretreatment cow udder firmness predicted clinical cure. Firm udders were less likely to cure clinically. Irrespective of treatment regimen, new infection rates with pathogens other than Staph. aureus were higher (42\%) after bacteriological cure than after nonbacteriological cure $(22 \%)$ and cured cows had a significantly lower SCC. In conclusion, independent of the treatment protocol, cows with an SCC $<250,000$ cells/mL before treatment showed a higher probability of bacteriological cure. It appears that successful treatment of clinical Staph.
\end{abstract}

Received September 25, 2012.

Accepted February 7, 2013.

${ }^{1}$ Corresponding author: j.swinkels@gddeventer.com aureus mastitis with cefquinome is associated with an increased number of new infections with coagulasenegative staphylococci. Extended treatment improved clinical, but not bacteriological, cure rates compared with the standard treatment. These results indicate that extending treatment of clinical Staph. aureus mastitis with cefquinome should not be recommended.

Key words: dairy cow, lactation, mammary gland, antimicrobial

\section{INTRODUCTION}

Contagious mastitis has been successfully controlled in recent decades on many farms in many countries due to the large scale adoption of the 5-point plan: optimization of milking and milking machine, blanket dry cow treatment, postmilking teat disinfection, treatment of clinical mastitis, and culling of chronically infected cows (Neave et al., 1969). As a result, the incidence of contagious pathogens, such as Streptococcus agalactiae and Staphylococcus aureus, has declined, resulting in a dramatic decrease of the average bulk milk SCC (BMSCC) in the majority of European countries. Despite this, Staph. aureus remains an important mastitis-causing pathogen on many farms, even when BMSCC is low (Barkema et al., 1998; Olde Riekerink et al., 2010).

An important reason the prevalence of Staph. aureus remains high in herds is the degree of difficulty to cure existing infections, leading to both repeat clinical episodes and spreading of bacteria to herd mates. Bacteriological cure (BC) of Staph. aureus mastitis during lactation is generally low, both for subclinical (Sol et al., 1997) and clinical cases (Sol et al., 2000; Bradley and Green, 2009), and is mainly dependent on the duration of infection, the bacterial strain, and the duration of treatment (Barkema et al., 2006). Also, some Staph. aureus strains have a stronger clinical manifestation than others (Zadoks et al., 2000; Haveri et al., 2005; Fournier et al., 2008), a lower persistence, and a higher probability of cure (Haveri et al., 2005). 
Subclinical Staph. aureus-infected cows can be selected for treatment based on their estimated probability of cure. In Staph. aureus clinical mastitis (CM), however, treatment is necessary to fight the clinical symptoms and to bring the cow back into production as soon as possible. Increased duration of treatment is often used in practice because it is an easy way to possibly improve the probability of cure. Research showing the beneficial effect of extended antimicrobial treatment of subclinical Staph. aureus mastitis during lactation are numerous and conclusive (Gillespie et al., 2002; Oliver et al., 2004; Deluyker et al., 2005). However, studies of extended antimicrobial treatment of clinical Staph. aureus mastitis are limited and less conclusive, showing a better effect (Jarp et al., 1989), only a numerical difference (Pyörälä and Pyörälä, 1998), or a significantly higher cure only for $\beta$-lactamase negative Staph. aureus cases (Sol et al., 2000). Thus, more research on the effects of extended treatment is needed for clinical Staph. aureus mastitis.

Cefquinome is a broad-spectrum cephalosporin which is commonly used for the intramammary (IMM) treatment of CM throughout Europe, where it has been approved for the treatment of CM caused by the major mastitis-causing pathogens, including Staph. aureus. The objective of this study is to compare different aspects of the efficacy of a standard versus an extended duration of IMM cefquinome treatment against clinical Staph. aureus mastitis.

\section{MATERIALS AND METHODS}

\section{Study Design}

This was a multi-centered, nonblinded, randomized, positive controlled clinical trial that was conducted in 5 countries: France, Hungary, Italy, the Netherlands, and the United Kingdom. The protocol was in accordance with the note for Guidance on statistical principles for veterinary clinical trials (EMEA, 2002), the legal requirements in the countries where it was implemented, and the European Guideline for the conduct of efficacy studies for intramammary products for use in cattle (EMEA, 2003).

Lactating cows with clinical Staph. aureus mastitis from different herds were randomly assigned to 2 treatment groups, receiving either a standard $1.5-\mathrm{d}$ or an extended 5-d IMM cefquinome treatment. Milk samples were taken around 14 and $21 \mathrm{~d}$ after the last treatment to determine the primary efficacy criteria, BC, and clinical cure (CC).

\section{Animals and Herds}

No specific animal management or housing was required for the selection of herds. Herd-specific data, such as herd size (number of dairy cows), herd management (housing, bedding, feeding), or udder health management (average milking interval, teat disinfecting practices, that is, pre- and postdipping and blanket, selective or no dry cow treatment), were recorded, as well as the 3 most recent BMSCC.

\section{Criteria for Selection of Clinical Mastitis Cases}

Lactating cows with $\mathrm{CM}$ in a single quarter were included in this study. Clinical mastitis was defined as a quarter with clinical signs (swelling, heat, pain) or any changes in the appearance of milk, with or without associated general clinical signs. For the included cows, historic cow data, such as breed, date of birth, number of lactation, date of last calving, estimated or measured milk yield at time of treatment, cow SCC, and history of previous mastitis cases, were recorded. Excluded were cows with $\mathrm{CM}$ occurring less than 30 d from the planned day of drying-off, cows with severe systemic signs needing other systemic treatment, cows with other intercurrent diseases at the time of $\mathrm{CM}$, cows given systemic or IMM anti-inflammatory or antimicrobial treatments within a $30-\mathrm{d}$ period before inclusion, cows with visible teat damage, and cows with daily milk yield less than $5 \mathrm{~kg}$ before the onset of clinical signs.

\section{Postadmission Withdrawal}

A cow was withdrawn after enrolment if the pretreatment milk sample was contaminated ( $>2$ bacteria species) or if no Staph. aureus was isolated. If 2 bacteria were cultured pretreatment, Staph. aureus had to be the primary pathogen, having equal or more bacteria than the other pathogen based on semiquantitative analysis (low/moderate/high), to keep the cow in the study. Also withdrawn were cows experiencing an adverse event, injury, or illness, including mastitis in another quarter or treatment with another antimicrobial or anti-inflammatory. If any other significant deviation from the protocol occurred, the corresponding case was also withdrawn from the study.

\section{Number of Animals}

The tested hypothesis was that the extended treatment resulted in a higher cure rate $(50 \%)$ than the standard treatment (25\%). Based on a one-sided, Chisquared test with type I error $\alpha=0.05$ and type II error $\beta=0.20$, the estimated sample size is 48 cows per treatment group. Assuming $70 \%$ bacteriological positive and noncontaminated milk cultures, a Staph. aureus prevalence among these of $10 \%$, and $10 \%$ exclu- 
sion for adverse events and major deviations, a total of approximately 1,500 cows should be included to reach the target sample size. However, during the study it became clear that the actual prevalence of Staph. aureus in noncontaminated bacteriological-positive cultures was much higher than estimated (not 10\% but 17.7\%); thus, the trial could be stopped before reaching the 1,500 included cows. Finally, 1,217 cows with CM were screened.

\section{Treatment and Randomization}

Eligible cows were treated IMM in the infected quarter with $75 \mathrm{mg}$ of cefquinome sulfate (Cobactan LC, MSD Animal Health, Boxmeer, the Netherlands) according to one of the following treatment protocols: extended treatment group $=3$ infusions of one tube at 12-h intervals, followed by 3 infusions of one syringe at 24-h intervals (5 d); or standard treatment group $=3$ infusions of one tube at 12-h intervals between each infusion $(1.5 \mathrm{~d})$. To ensure the homogeneity of treatment groups, cows were allocated randomly to either the extended or the standard treatment group. A randomization list was established in advance for each country using SAS software (version 9.1; SAS Institute Inc., Cary, NC). Each investigator received a set of numbered therapeutic units containing either 6 or 3 tubes. When a new animal was enrolled, the investigator had to give the therapeutic unit with the lowest number as indicated on the randomization list. Any adverse event, whether or not considered treatment related, was recorded and thoroughly reviewed.

\section{Milk Sampling}

At inclusion, milk sampling for bacteriology was performed from the affected quarter of all clinical cases. First and second post-treatment quarter milk samples were only taken if Staph. aureus was cultured from the sample at inclusion. The first post-treatment milk sample was collected 14 to $17 \mathrm{~d}$ after the last IMM infusion, and the second was taken 7 to $10 \mathrm{~d}$ later. Therefore, in the extended treatment group, the first post-treatment milk sample was taken between d 18 and 21 and the second post-treatment sampling was taken between $\mathrm{d} 25$ and 31 . In the standard treatment group, the 2 post-treatment samplings were between $\mathrm{d}$ 15 and 18 and between d 22 and 28, respectively.

Quarter milk sampling was done by the farmer, a technician, or the local investigator from the foremilk before milking, after discarding 3 to 5 streams of milk, according to a strict hygiene protocol. All samples were kept cool $\left(1-8^{\circ} \mathrm{C}\right)$ before transport, at ambient temperatures during transport, and kept cool again upon arrival and during analysis in a centralized laboratory (IDEXX, Alfortville, France). In case the shipment was delayed (i.e., sample taken during the weekend), samples were frozen until transport. Two quarter milk samples for SCC were taken, 1 at inclusion and 1 just after the second post-treatment milk sample for bacteriology. At least $2 \mathrm{~mL}$ of milk were collected, identified properly, and sent to the laboratory.

\section{Laboratory Procedures}

Milk samples were plated with an inoculum size of $0.1 \mathrm{~mL}$ (Walker et al., 2010) and bacterial colonies were identified according to National Mastitis Council guidelines (NMC, 1999). Also, semiquantitative analysis (low/moderate/high) of the isolated bacterial species was performed.

A milk sample was considered contaminated if 3 or more bacterial species were isolated. In case of a contaminated sample at inclusion, the animal was withdrawn from the study. If one other bacterial species, besides Staph. aureus, was isolated as well, the additional bacterium was identified.

To determine cefquinome resistance in vitro, all the Staph. aureus strains isolated from pretreatment milk samples were shipped to MSD Animal Health Reasearch and Development for the determination of their MIC of cefquinome. The MIC were determined using the broth microdilution method according to Clinical and Laboratory Standards Institute (CLSI) document M31-A3 (CLSI, 2008). Additionally, the production of $\beta$-lactamase by the Staph. aureus strains was investigated by the nitrocefin disc-based test (Cefinase disc, Becton Dickinson, Franklin Lakes, NJ). All SCC determinations were performed using a DeLaval (Tumba, Sweden) cell counter. If the SCC of a sample could not be determined due to clotting in the milk, a value equal to the upper limit of quantification of the method $(4,000 \times 1,000$ cells $/ \mathrm{mL})$ was used for calculations.

\section{Clinical Examination}

At inclusion and after the first and second posttreatment milk sampling, a clinical examination was performed by the local investigator. Rectal temperature, general condition, udder swelling (assessed by observation), udder firmness and induration (assessed by palpation), udder pain (assessed by the cow's reaction), and milk quality (assessed by observation) were scored on a clinical examination form ranging from normal (score 0 ), slightly (score 1 ), moderately (score 2 ), and severely affected (score 3 ). At least $7 \mathrm{~d}$ were allowed between the first and second post-treatment clinical examination. 


\section{Definitions}

Bacteriological cure was defined as the absence of Staph. aureus in both post-treatment milk samples. The presence of Staph. aureus in one or in both of the posttreatment milk samples was considered a treatment failure. In case 1 or 2 of the post-treatment samples were noninterpretable ( $>2$ pathogens in a sample or noncompliance to the treatment protocol), the case was excluded from $\mathrm{BC}$ analysis.

A new infection was defined as the presence, in 1 or 2 of the post-treatment samples, of a pathogen other than Staph. aureus and a pathogen other than any pathogen isolated pretreatment. Clinical cure was defined as a cow in normal condition having no clinical sign of mastitis in milk quality or udder aspects (firmness, swelling, pain) at the first post-treatment evaluation. The presence of any clinical sign in any clinical parameter at the first post-treatment sample was considered a clinical treatment failure. Quarter SCC cure was defined as an SCC of $\geq 200,000$ cells/mL of the clinically affected quarter at inclusion that was reduced to $<200,000$ cells $/ \mathrm{mL}$ in the second post-treatment sample.

\section{Statistical Analysis}

All data were reviewed by the study supervisor to check for clinical consistency. They were entered electronically by an automatic system of data lecture (FORMS 5.2; ReadSoft, Helsingborg, Sweden). All the electronically entered data $(100 \%)$ used for evaluation of $\mathrm{BC}$ were checked against raw data, and $10 \%$ of electronically entered data of the $\mathrm{CC}$ and $\mathrm{SCC}$ were checked against the raw data.

Bacteriological culturing was analyzed using a mixed model logistic regression analysis. For all regression models the linear predictor was given by

$$
\begin{gathered}
\text { Logit }(\text { cure })=\text { lactation }+\mathrm{DIM}+\text { herd size } \\
+ \text { BMSCC }+ \text { pretreatment SCC }+ \text { Staph. aureus } \\
\text { MIC }+ \text { Staph. aureus } \mathrm{CFU}+\text { Staph. aureus } \\
\text { Betalact }+ \text { treatment }+ \text { herd (random })+\mathrm{e},
\end{gathered}
$$

where cure is either $\mathrm{CC}$ or $\mathrm{BC}$; lactation is in 3 categories $(1,2$, and $3+$ ); DIM is in three 100-d categories; herd size is in categories of 100 animals; BMSCC is the BMSCC before treatment; pretreatment SCC is the cow SCC before treatment; Staph. aureus MIC is the MIC value at $0.25,0.5,1$, or $2 \mu \mathrm{g} / \mathrm{mL}$; Staph. aureus $\mathrm{CFU}$ is an indicator for cfu of Staph. aureus at the initial sampling; Staph. aureus Betalact is an indicator variable indicating the presence or absence of $\beta$-lactamase; and treatment indicated extended or standard duration of treatment. All of these factors were included as a fixed effect, and e was a binomial error term. $\beta$-Lactamase production of Staph. aureus is included in the model because it is a potential confounder due to its association with a lower probability of cure (Osterås et al., 1999; Sol et al., 2000). A random herd effect was included in the model with herd as a unique herd identifier. The CC model also included the results of the clinical investigation at the time of diagnosis. The clinical investigation included udder firmness, swelling, pain, milk characteristics, body temperature, and cow attitude.

A backward, stepwise regression analysis was performed. In the final model, all 2-way interactions were evaluated. For all outcome variables, treatment was compared with the control group with significance defined as $P>0.05$.

\section{RESULTS}

\section{Enrolled Cows}

The cows in the study were from a diverse population. They were from 5 different European Union countries and originated from 68 different herds with a wide range of geometric BMSCC (237,000-520,000 cells/mL) and clinical Staph. aureus incidence (Table 1). A total of 1,217 cows with CM were sampled pretreatment for bacteriological examination. In 646 milk samples other bacteria than Staph. aureus were cultured, 286 samples showed no growth, and 70 samples were contaminated, leaving 215 cows with confirmed clinical Staph. aureus mastitis. This corresponds to an average prevalence of Staph. aureus of $17.7 \%$ among CM samples $(215 / 1,217)$. After inclusion, another 9 cows were withdrawn from the study due to noncompliance to the study protocol. A total of 206 clinical Staph. aureus mastitis cases were included, 161 containing Staph. aureus only and 45 mixed cultures containing an additional pathogen. Additional pathogens to Staph. aureus were Streptococcus uberis (16), esculine-positive streptococci (9), Streptococcus dysgalactiae (6), CNS (4), Pseudomonas spp. (4), Escherichia coli (2), Enterobacteriaceae spp. (2), Klebsiella pneumonia (1), and Arcanobacterium pyogenes (1). Finally, these 206 included cases, 114 in the extended treatment group and 92 in the standard treatment group, completed the study and were included in the statistical analysis (Table 1).

\section{Homogeneity of Treatment Groups}

The data of the 2 treatment groups were compared and tested statistically with a Student's $t$-test or a 
Table 1. Description of country-specific traits and total traits

\begin{tabular}{|c|c|c|c|c|c|c|}
\hline Item & \multicolumn{5}{|c|}{ Country $^{1}$} & Total \\
\hline No. of herds & 35 & 8 & 14 & 4 & 7 & 68 \\
\hline $\operatorname{BMSCC}^{3}(\times 1,000$ cells $/ \mathrm{mL})$ & 309 & 520 & 313 & 237 & 256 & \\
\hline Total of clinical cases (No.) & 349 & 184 & 433 & 94 & 157 & 1,217 \\
\hline Staph. aureus $\mathrm{CM}^{4}$ (No.) & 53 & 58 & 64 & 28 & 12 & 215 \\
\hline $\mathrm{BC}^{5}$ extended, No. $(\%)$ & $8(31)$ & $2(8)$ & $13(52)$ & $7(58)$ & $0(0)$ & $30(33)$ \\
\hline BC standard, No. (\%) & $2(11)$ & $4(18)$ & $14(61)$ & $5(62)$ & $0(0)$ & $25(33.3)$ \\
\hline New infections, No. (\%) & & & & & & $47 / 166(28)$ \\
\hline After BC, No. (\%) & & & & & & $23 / 55(42)$ \\
\hline After non-BC, No. (\%) & & & & & & $24 / 111(22)$ \\
\hline $\mathrm{CC}^{6}$ extended, No. (\%) & $20(67)$ & $7(24)$ & $31(100)$ & $14(100)$ & $3(75)$ & $75 / 108(69.4)$ \\
\hline
\end{tabular}

${ }^{1} \mathrm{FR}=$ France, $\mathrm{HU}=$ Hungary, IT = Italy, NL = the Netherlands, UK = United Kingdom.

${ }^{2}$ Median herd size.

${ }^{3}$ Bulk milk somatic cell count, geometric mean.

${ }^{4}$ Clinical mastitis.

${ }^{5}$ Bacteriological cure.

${ }^{6}$ Clinical cure.

${ }^{7}$ Quarter somatic cell count cure, clinically affected quarters at inclusion that had a QSCC $<200,000$ cells/mL after the second posttreatment sample.

Kruskal-Wallis one-way ANOVA for homogeneity (Table 2). No significant differences $(P>0.05)$ were found between the age, parity, DIM, milk production, BW, CM history, cow SCC, rectal temperature, or $\beta$-lactamase production between the extended and the standard treatment group.

\section{Antimicrobial Susceptibility In Vitro}

The MIC of cefquinome for the isolated Staph. aureus strains were distributed over a narrow range, from 0.25 to $2 \mu \mathrm{g} / \mathrm{mL}$, with $98 \%$ of the strains $(209 / 213)$ having an $\mathrm{MIC}<1 \mu \mathrm{g} / \mathrm{mL}$. None of the strains was resistant to cefquinome. For most of the countries the $\mathrm{MIC}_{50}$ was $0.5 \mu \mathrm{g} / \mathrm{mL}$, except Italy, where it was one dilution step higher $(1 \mu \mathrm{g} / \mathrm{mL})$. Despite this slight difference, strains collected in Italy had a good susceptibility against cefquinome, with $96 \%$ of the strains $(60 / 64)$ having an $\mathrm{MIC}<1 \mu \mathrm{g} / \mathrm{mL}$.

\section{$B C$}

Twenty-three clinical cases in the extended treatment group and 17 cases in the standard treatment group

Table 2. Homogeneity of data between the two treatment groups ${ }^{1}$

\begin{tabular}{lccc}
\hline Item & Standard & Extended & $P$-value \\
\hline Age (y) & $5.2(2.0)$ & $4.9(2.1)$ & 0.35 \\
Parity & $2(2-4)$ & $2(2-4)$ & 0.43 \\
DIM (d) & $149.8(87.3)$ & $147.2(93.6)$ & 0.86 \\
Milk production (kg) & $26.7(8.4)$ & $26.4(8.4)$ & 0.82 \\
BW (kg) & $649.4(71.0)$ & $646.5(73.4)$ & 0.78 \\
$\mathrm{CM}^{2}$ history (No.) & $1(0-2)$ & $1(0.1)$ & 0.83 \\
Log cow SCC & $6.1(1.4)$ & $6.0(1.4)$ & 0.65 \\
Rectal temperature $\left({ }^{\circ} \mathrm{C}\right)$ & $38.6(0.4)$ & $38.6(0.4)$ & 0.96 \\
\hline
\end{tabular}

${ }^{1}$ Most parameters were tested by Student's $t$-test and are shown as the mean and the SD in parentheses. For parity and clinical mastitis history, a Kruskal-Wallis one-way ANOVA was performed to better describe the data, these are shown as medians with their $25 \%$ and $75 \%$ intervals, respectively, in parentheses.

${ }^{2}$ Clinical mastitis. 
Table 3. Final mixed model logistic regression model of bacteriological cure

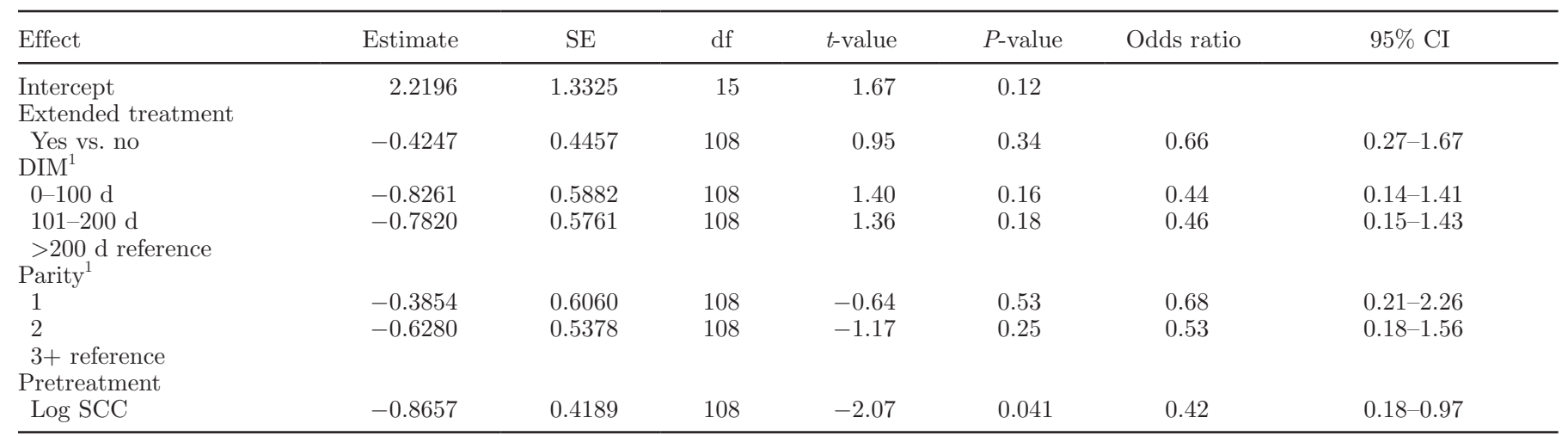

${ }^{1}$ Days in milk and parity were kept in the model because they acted as confounders.

were excluded from the analysis of $\mathrm{BC}$ due to noninterpretable bacteriological results, leaving 91 (114-23) cases in the extended treatment group and 75 (92-17) in the standard treatment group. The overall $\mathrm{BC}$ showed no difference between treatment groups: $33.0 \%$ (30/91) after extended treatment and 33.3\% (25/75), after standard treatment (Table 1). Least squares means estimates for BC of Staph. aureus infections during lactation were $34 \%$ (SE 9.9\%) for the standard treatment group and $27 \%$ (SE $8.4 \%$ ) for the extended treatment group. Logistic regression results of $\mathrm{BC}$ are shown in Table 3. In the final model, extended therapy was not significantly different from the control treatment [odds ratio $(\mathbf{O R})=0.66,95 \%$ CI $(0.27-1.67)$ ]

At the country level, BC also showed no difference per treatment group, except for France, where the cure after extended treatment was significantly better (31\%) than after the standard treatment (11\%; Table 1). Bacteriological cure at the country level showed a wide variety, with low cure rates in Hungary and the United Kingdom, ranging from 0 to $18 \%$, and high cure rates in Italy and the Netherlands, ranging from 52 to $62 \%$.

Both DIM and parity were nonsignificant risk factors for BC (Table 3). The only significant predictor variable was the pretreatment cow SCC; a higher pretreatment cow SCC indicated a lower probability of cure $(\mathrm{OR}=0.42,95 \%$ CI $[0.18-0.97])$. None of the herd-level variables indicated in the Material and Methods section were statistically significant. Parity was maintained in the final model as it acted as a confounder. Removing lactation number from the model did not affect the significance of the treatment variable. The random effect for herd was estimated at 1.1 (SE 0.78) and was not statistically significant. The overall percentage of $\beta$-lactamase-producing Staph. aureus strains was $43 \%$, but varied widely between countries, from a noticeably low percentage of $7 \%$ in the Netherlands to $59 \%$ in France (Table 1).
Irrespective of treatment protocol, the $\mathrm{BC}$ for $\beta$-lactamase-positive strains was lower $(28.8 \%)$ than for $\beta$-lactamase-negative strains (36.6\%), although the difference was not significant (Chi-squared, $P=0.29$ ). Extended treatment did not have an effect compared with standard treatment within $\beta$-lactamase-negative (35.8 and $37.5 \%$, respectively) nor within $\beta$-lactamasepositive (28.9 and $28.6 \%$, respectively) Staph. aureus strains.

\section{CC}

Six cases were excluded from the analysis of the CC in the extended treatment group; 4 cases related to mastitis observed in another quarter, 1 case related to missing data, and 1 case that was noncompliant with the treatment protocol. Eight cases were excluded in the analysis of the $\mathrm{CC}$ in the standard treatment group; 3 cases related to mastitis observed in another quarter, 1 case related to missing data, and 4 cases were noncomplaint with the treatment protocol. One-hundred and eight cases (114-6) were left for analysis in the extended treatment group and $84(92-8)$ in the standard treatment group.

The CC in the standard versus the extended treatment groups was $61.9(52 / 84)$ and $69.4 \%$ (75/108), respectively (Table 1). Logistic regression results of CC of Staph. aureus mastitis during lactation were $60 \%$ (SE $19 \%$ ) for the standard treatment group and $82 \%$ (SE $12 \%$ ) for the extended treatment group. The final model for CC is shown in Table 4. In the final model, CC after extended treatment was significantly better compared with the standard treatment $(\mathrm{OR}=3.03,95 \% \mathrm{CI}$ [1-9.17]). The only significant predictor variable for CC was the pretreatment cow udder firmness $(\mathrm{OR}=0.40$, 95\% CI [0.20-0.79]). A firm udder at palpation at the time of diagnosis of CM predicted a lower probability of CC. None of the herd-level variables were statisti- 
Table 4. Final mixed model logistic regression model of clinical cure

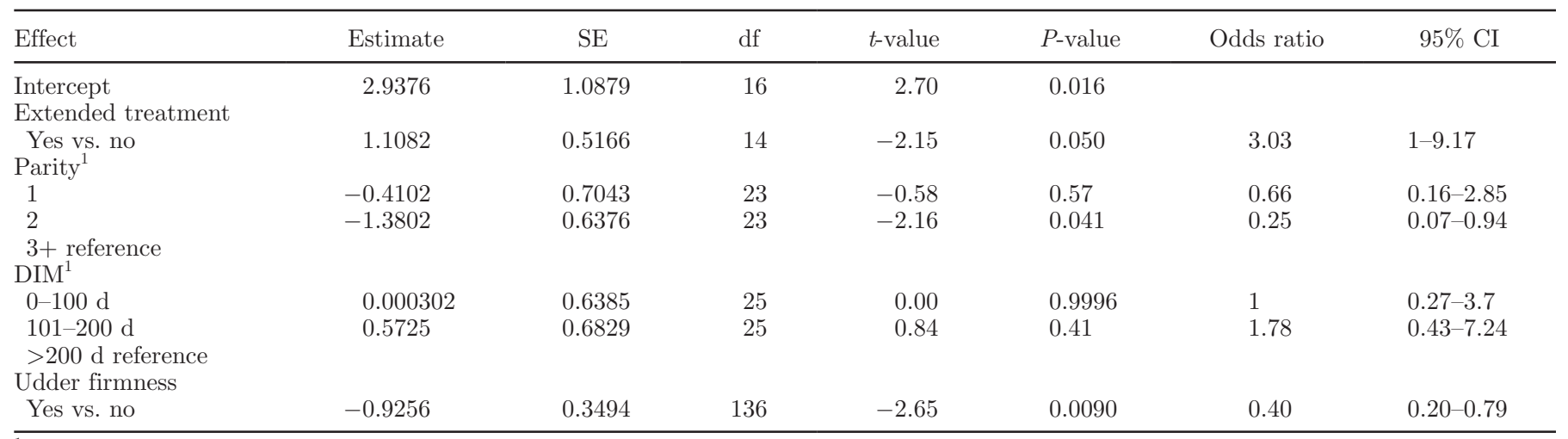

${ }^{1}$ Parity and DIM were kept in the model because they acted as confounders.

cally significant. The DIM and parity categories were maintained in the final model because they acted as a confounder. Removing the lactation number from the model did not affect the significance of the treatment variable. The random effect for herd was estimated at 7.1 (SE 4.4) and was borderline statistically significant. Further evaluation of herds indicated that herds in one country (Hungary) had a marked lower CC rate than the other countries (Table 1).

\section{SCC}

The overall median SCC in the clinically affected quarters at 21 to $27 \mathrm{~d}$ after the last treatment was lower for the 5 -d treatment $(1,233,000$ cells $/ \mathrm{mL})$ than for the 1.5 -d treatment $(2,076,000$ cells $/ \mathrm{mL})$, but the difference was not significant due to the large variance. The median SCC of the bacteriologically cured quarters (33.5\%), for 5- and 1.5-d treatment was low (112,000 and 130,000 cells $/ \mathrm{mL}$, respectively), when compared with nonbacteriologically cured quarters $(66.5 \% ; 2,520,000$ and 2,954,000 cells $/ \mathrm{mL}$, respectively). No difference in quarter SCC was found between treatment groups. The percentage of quarters with an SCC $<200,000$ cells/ $\mathrm{mL}$ (quarter SCC cure) after treatment was low: $30.7 \%$ after 5-d treatment and $23.6 \%$ after 1.5 -d treatment (Table 1), which was 3 to $10 \%$ lower than BC.

\section{New Infections}

The percentage of new infections was comparable and therefore nonsignificant between the treatment groups: $28.6 \%(26 / 91)$ after the extended treatment and 28\% (21/75) after the standard treatment (Table 1). Interestingly, irrespective of treatment protocol, the percentage of new infections was much higher for bacteriologically cured quarters $(42 \%[23 / 55])$ than for the noncured quarters $(22 \%$ [24/111]; Table 1$)$. The major- ity (around 40\%) of the new infections were caused by CNS irrespective of treatment protocol.

\section{DISCUSSION}

This study showed that standard IMM treatment of clinical Staph. aureus mastitis with cefquinome resulted in a BC rate of $33.3 \%$. This BC rate is comparable to the standard treatment cure rates of clinical Staph. aureus mastitis found in the study of Bradley and Green (2009; 31.9\%), Pyörälä and Pyörälä (1998; 29\%), Jarp et al. (1989; 38.8\%), and Sol et al. (2000; $38 \%$, $\beta$-lactam-positive strains) but lower than the $48 \%$ ( $\beta$-lactam-negative strains) cure rates found in the study of Sol et al. (2000) after standard treatment. However, a comparison of cure rates between trials has to be done with care because of different definitions for cure or different conditions in different areas. As in our study, the study of Bradley and Green (2009) was performed in multiple European countries (United Kingdom, Germany, and France), whereas the study of Sol et al. (2000) was performed in a more restricted area (the eastern part of the Netherlands), suggesting that local results cannot always be extrapolated to larger geographic areas. Also, differences were observed in our study in cure rates between countries. The problem in extrapolating outcomes of Staph. aureus treatment studies from one geographical area to another can be caused by many factors, such as differences in Staph. aureus strains. This was confirmed by the large differences in the prevalence of $\beta$-lactamase-producing Staph. aureus strains between countries (Table 1).

Our finding that extended treatment of clinical Staph. aureus did not result in an improved overall BC cure compared with standard treatment is in contrast with reports from studies on clinical (Jarp et al., 1989; Pyörälä and Pyörälä, 1998; Sol et al., 2000) and subclinical Staph. aureus mastitis (Gillespie et al., 2002; 
Oliver et al., 2004; Deluyker et al., 2005) that describe an increased cure after extended treatment. Based on these previous studies, it seems that extended treatment is the best choice when treating Staph. aureus mastitis (Roy et al., 2009). Including high BMSCC Staph. aureus problem farms, because such farms are more interested to participate in the study, increased the probability of isolating Staph. aureus. On this type of farms, infection pressure of Staph. aureus is relatively high, possibly resulting in more reinfection of initially cured cows, which, in case the reinfection was with Staph. aureus, were recorded as noncured.

We found a much higher new infection rate after BC (42\%) when compared with non-BC $(22 \%$; Table 1), confirming an increased quarter sensitivity for a new IMI after cure, as previously shown by Zadoks et al. (2001). We hypothesized that, to prevent new infections after cure, extended treatment should be restricted to farms with low infection pressure, likely corresponding to good udder health management, as has been previously suggested in a theoretical model by Barlow et al. (2009). Further research is needed to substantiate this hypothesis in the field. Interestingly, the majority $( \pm 40 \%)$ of the new infections after treatment were caused by CNS, which is similar to the findings of Bradley and Green, (2009) and Sampimon et al. (2010), who reported that CNS becomes more important on farms with low BMSCC and a low prevalence of Staph. aureus. It seems likely that the absence of Staph. aureus or, as in our study, the clearance of Staph. aureus by treatment creates a window of opportunity for opportunistic CNS to invade the udder. It has been reported that $30 \%$ of the CNS species Staphylococcus epidermidis carry the mecA gene (Sampimon et al., 2011), much higher than has been reported in Staph. aureus. The possible relation between mecA-positive CNS and Staph. aureus needs to be further clarified.

Additionally, on Staph. aureus problem farms where BMSCC is high, Staph. aureus infections are not only more prevalent, but also more chronic, resulting in lower cure rates (Barkema et al., 2006). This may explain the low $\mathrm{BC}$ rates in Hungary, where the average BMSCC was high $(520,000$ cells/mL; Table 1$)$. These observations at the bulk tank level are likely to be related to the findings at the individual cow level, where we did find a significantly lower $(\mathrm{OR}=0.42,95 \%$ CI [0.18-0.97]) BC in cows with a high pretreatment SCC $(\geq 250,000$ cells $/ \mathrm{mL})$ compared with cows with a low pretreatment SCC $(<250,000$ cells $/ \mathrm{mL})$ independently of treatment protocol (Table 3 ).

A lack of antimicrobial susceptibility to cefquinome could potentially have contributed to low BC in both treatment groups. Although isolated Staph. aureus strains had comparable low MIC levels in all countries, showing good susceptibility in vitro, this does not necessarily correspond to good susceptibility in vivo. Another explanation for the apparent therapy resistance of Staph. aureus in vivo is biofilm formation, hindering the antibiotic to reach the site of infection (Melchior et al., 2006). Also, methicillin-resistant Staph. aureus (MRSA) caused by the expression of the mecA gene is of particular interest due to its susceptibility for $\beta$-lactam antibiotics in vitro, but resistance to almost all $\beta$-lactam antibiotics in vivo. Cattle are a potential reservoir for MRSA for the human population and, if transferred, can cause infections in humans that are difficult to cure (Holmes and Zadoks, 2011). Reports on MRSA in dairy cattle in different European countries, however, show that the prevalence is relatively low (Hendriksen et al., 2008). A more recent report shows the prevalence of MRSA to be below $2 \%$ at the quarter level (Vanderhaeghen et al., 2010). Because we did not test for the mecA gene in our Staph. aureus isolates, we are not able to determine its prevalence in our study. Potentially, presence of mecA resistance could have contributed to a lower bacteriological cure. However, we do not think that mecA resistance had a big influence on the comparison in efficacy between treatment groups because of the expected low prevalence of methicillin resistance and the likely equal distribution among treatment groups.

Our study shows an improvement in CC of Staph. aureus mastitis after extended treatment compared with the standard treatment. It was surprising to find a difference between $\mathrm{CC}$ and $\mathrm{BC}$, as one would expect these parameters to be correlated. We hypothesized that extended treatment reduced the number of Staph. aureus cfu to a level at which clinical signs disappeared while leaving enough bacteria for a positive culture. Because we only registered the number of cfu in the milk samples before but not after treatment, this hypothesis could not be evaluated. Another explanation for the discrepancy between $\mathrm{CC}$ and $\mathrm{BC}$ is reinfection with Staph. aureus. Clinical cure was measured $14 \mathrm{~d}$ posttreatment, whereas $\mathrm{BC}$ was measured both on d 14 and 21 post-treatment. Equal BC and $\mathrm{CC}$ at d 14 posttreatment may, after subsequent reinfection with Staph. aureus in the 7 consecutive days, result in a relatively lower BC than CC. Of the clinical parameters measured at inclusion, only udder firmness remained in the final model, indicating that a firm udder at palpation at the time of diagnosis of CM predicted a lower probability of CC. The practical implication of this finding for treatment decisions of CM is not clear, although it could be helpful in predicting the resolution of clinical signs after treatment.

Extending exposure of bacteria to antimicrobials potentially increases the selection of resistant bacteria. 
Because extended treatment only showed an effect on $\mathrm{CC}$, which is based on subjective judgment and not on BC, extending treatment of Staph. aureus CM cannot be justified.

To minimize bias, this positively controlled field trial should have been double-blinded. This was not possible because the treatment groups had a different number of tubes, which could not be hidden from the investigators and the farmers. As laboratory personnel were unaware of treatment group allocations, the absence of a double-blind design is unlikely to have seriously affected the outcome of the BC. For the CC, however, this was different because the same investigator, who randomly selected the treatment protocol and applied the first tube, could potentially have remembered the treatment protocol while scoring the CC 2 and $3 \mathrm{wk}$ later. Although we cannot exclude bias of the investigators judgment for $\mathrm{CC}$, we assumed that in the majority of cases they did not remember the treatment protocol while judging CC later on.

\section{CONCLUSIONS}

In conclusion, independent of the treatment protocol, cows with SCC $<250,000$ cells $/ \mathrm{mL}$ before treatment showed a higher probability of bacteriological cure. It appears that successful treatment of clinical Staph. aureus mastitis is associated with an increased number of new infections with CNS. Extended treatment of clinical Staph. aureus with cefquinome resulted in a higher $\mathrm{CC}$ but not $\mathrm{BC}$ than did standard treatment. These results indicate that extending treatment of clinical Staph. aureus mastitis should not be recommended.

\section{REFERENCES}

Barkema, H. W., Y. H. Schukken, T. J. G. M. Lam, M. L. Beiboer, H. Wilmink, G. Benedictus, and A. Brand. 1998. Incidence of clinical mastitis in dairy herds grouped in three categories by bulk milk somatic cell counts. J. Dairy Sci. 81:411-419.

Barkema, H. W., Y. H. Schukken, and R. N. Zadoks. 2006. Invited review: The role of cow, pathogen, and treatment regimen in the therapeutic success of bovine Staphylococcus aureus mastitis. J. Dairy Sci. 89:1877-1895.

Barlow, J. W., L. J. White, R. N. Zadoks, and Y. H. Schukken. 2009. A mathematical model demonstrating indirect and overall effects of lactation therapy targeting subclinical mastitis in dairy herds. Prev. Vet. Med. 90:31-42.

Bradley, A. J., and M. J. Green. 2009. Factors affecting cure when treating bovine clinical mastitis with cephalosporin-based intramammary preparations. J. Dairy Sci. 92:1941-1953.

CLSI (Clinical and Laboratory Standards Institute). 2008. Performance standards for antimicrobial disk and dilution susceptibility tests for bacteria isolated from animals; approved standard - Third edition. CLSI document M31-A3. CLSI, Wayne, PA.

Deluyker, H. A., S. N. Van Oye, and J. F. Boucher. 2005. Factors affecting cure and somatic cell count after pirlimycin treatment of subclinical mastitis in lactating cows. J. Dairy Sci. 88:604-614.

EMEA (European Agency for the Evaluation of Medicinal Practices). 2002. Guideline on statistical principles for veterinary clini- cal trials (EMEA/CVMP/816/00-Final). Eur. Agency Eval. Med. Pract., London, UK.

EMEA (European Agency for the Evaluation of Medicinal Practices). 2003. Guideline for the conduct of efficacy studies for intramammary products for use in cattle (EMEA/CVMP/344/99-Final-Rev. 1). Eur. Agency Eval. Med. Pract., London, UK.

Fournier, C., P. Kuhnert, J. Frey, R. Miserez, M. Kirchhofer, T. Kaufmann, A. Steiner, and H. U. Graber. 2008. Bovine Staphylococcus aureus: Association of virulence genes, genotypes and clinical outcome. Res. Vet. Sci. 85:439-448.

Gillespie, B. E., H. Moorehead, P. Lunn, H. H. Dowlen, D. I. Johnson, K. C. Lamar, M. J. Lewis, S. J. Ivey, W. Hallberg, S. T. Chester, and S. P. Oliver. 2002. Efficacy of extended pirlimycin hydrochloride therapy for treatment of environmental Streptococcus spp. and Staphylococcus aureus intramammary infections in lactating dairy cows. Vet. Ther. 3:373-380.

Haveri, M., S. Taponen, J. Vuopio-Varkila, S. Salmenlinna, and S. Pyörälä. 2005. Bacterial genotype affects the manifestation and persistence of bovine Staphylococcus aureus intramammary infection. J. Clin. Microbiol. 43:959-961.

Hendriksen, R. S., D. J. Mevius, A. Schroeter, C. Teale, D. Meunier, P. Butaye, A. Franco, A. Utinane, A. Amado, M. Moreno, C. Greko, K. Stark, C. Berghold, A. L. Myllyniemi, D. Wasyl, M. Sunde, and F. M. Aarestrup. 2008. Prevalence of antimicrobial resistance among bacterial pathogens isolated from cattle in different European countries: 2002-2004. Acta Vet. Scand. 50:28.

Holmes, M. A., and R. N. Zadoks. 2011. Methicillin resistant S. aureus in human and bovine mastitis. J. Mammary Gland Biol. Neoplasia $16: 373-382$.

Jarp, J., H. P. Bugge, and S. Larsen. 1989. Clinical trial of three therapeutic regimens for bovine mastitis. Vet. Rec. 124:630-634.

Melchior, M. B., H. Vaarkamp, and J. Fink-Gremmels. 2006. Biofilms: A role in recurrent mastitis infections? Vet. J. 171:398-407.

National Mastitis Council. 1999. Laboratory Handbook on Bovine Mastitis. Natl. Mastitis Counc. Inc., Madison, WI.

Neave, F. K., F. H. Dodd, R. G. Kingwill, and D. R. Westgarth. 1969. Control of mastitis in the dairy herd by hygiene and management. J. Dairy Sci. 52:696-707.

Olde Riekerink, R. G. M., H. W. Barkema, D. T. Scholl, D. E. Poolea, and D. F. Keltond. 2010. Management practices associated with the bulk-milk prevalence of Staphylococcus aureus in Canadian dairy farms. Prev. Vet. Med. 97:20-28.

Oliver, S. P., B. E. Gillespie, S. J. Headrick, H. Moorehead, P. Lunn, H. H. Dowlen, D. L. Johnson, K. C. Lamar, S. T. Chester, and W. M. Mosely. 2004. Efficacy of extended ceftiofur intramammary therapy for treatment of subclinical mastitis in lactating dairy cows. J. Dairy Sci. 87:2393-2400.

Osterås, O., V. L. Edge, and S. W. Martin. 1999. Determinants of success or failure in the elimination of major mastitis pathogens in selective dry cow therapy. J. Dairy Sci. 82:1221-1231.

Pyörälä, S. H. K., and E. O. Pyörälä. 1998. Efficacy of parenteral administration of three antimicrobial agents in treatment of clinical mastitis; 487 cases (1989-1995). J. Am. Vet. Med. Assoc. 212:407-412.

Roy, J. P., L. DesCôteaux, D. DuTremblay, F. Beaudry, and J. Elsener. 2009. Efficacy of a 5-day extended therapy program during lactation with cephapirin sodium in dairy cows chronically infected with Staphylococcus aureus. Can. Vet. J. 50:1257-1262.

Sampimon, O., B. H. van den Borne, I. Santman-Berends, H. W. Barkema, and T. J. G. M. Lam. 2010. Effect of coagulase-negative staphylococci on somatic cell count in Dutch dairy herds. J. Dairy Res. 77:318-324.

Sampimon, O. C., T. J. G. M. Lam, D. J. Mevius, Y. H. Schukken, and R. N. Zadoks. 2011. Antimicrobial susceptibility of coagulasenegative staphylococci isolated from bovine milk samples. Vet. Microbiol. 150:173-179.

Sol, J., O. C. Sampimon, H. W. Barkema, and Y. H. Schukken. 2000 Factors associated with cure after therapy of clinical mastitis caused by Staphylococcus aureus. J. Dairy Sci. 83:278-284.

Sol, J., O. C. Sampimon, J. J. Snoep, and Y. H. Schukken. 1997. Factors associated with bacteriological cure during lactation after 
therapy for subclinical mastitis caused by Staphylococcus aureus. J. Dairy Sci. 80:2803-2808.

Vanderhaeghen, W., W. Cerpentier, C. Adriaensen, J. Vicca, K. Hermans, and P. Butaye. 2010. Methicillin-resistant Staphylococcus aureus (MRSA) ST398 associated with clinical and subclinical mastitis in Belgian cows. Vet. Microbiol. 144:166-171.

Walker, J. B., P. J. Rajala-Schultz, and F. J. DeGraves. 2010. The effect of inoculum volume on the microbiologic detection of naturally occurring Staphylococcus aureus intramammary infections. J. Vet. Diagn. Invest. 22:720-724.
Zadoks, R. N., H. G. Allore, H. W. Barkema, O. C. Sampimon, G. J. Wellenberg, Y. T. Grohn, and Y. H. Schukken. 2001. Cow- and quarter-level risk factors for Streptococcus uberis and Staphylococcus aureus mastitis. J. Dairy Sci. 84:2649-2663.

Zadoks, R., W. van Leeuwen, H. Barkema, O. C. Sampimon, H. Verbrugh, Y. H. Schukken, and A. van Belkum. 2000. Application of pulsed-field gel electrophoresis and binary typing as tools in veterinary clinical microbiology and molecular epidemiologic analysis of bovine and human Staphylococcus aureus isolates. J. Clin. Microbiol. 38:1931-1939. 